\title{
Kedi ve köpeklerde sistitis'in tanısında çift kontrast sistografi tekniğinin kullanımı ve tedavide enrofloksasin'in etkinliğinin araştırılması
}

\author{
Aslan KALINBACAK ${ }^{1}$ Öznur ATALAY2 ${ }^{2}$ Ali Haydar KIRMIZIGÜL ${ }^{3}$ \\ Didem NOYAN ${ }^{4}$ M. Çağrı KARAKURUM ${ }^{5}$
}

\begin{abstract}
${ }^{1}$ Ankara Üniversitesi, Veteriner Fakültesi, İç Hastalıklar Anabilim Dalı, Ankara; ${ }^{2}$ Erciyes Üniversitesi, Veteriner Fakültesi, İç Hastalıklar Anabilim Dalı, Kayseri; ${ }^{3}$ Kafkas Üniversitesi. Veteriner Fakültesi, İç Hastalıklar Anabilim Dalı, Kars; ${ }^{4}$ Ankara Üniversitesi, Veteriner Fakültesi, Radyoloji Bilim Dalı, Ankara; ${ }^{5}$ Akdeniz Üniversitesi , Veteriner Fakültesi, İç Hastalıklar Anabilim Dalı, Burdur
\end{abstract}

Özet: Bu çalışmada sistitisin tanısında çift kontrast sistografinin yararlılığ ve tedavisinde enrofloksasinin etkinliğinin araştırılması amaçlandı. Ankara Üniversitesi Veteriner Fakültesi İç Hastalıklar Anabilim Dalı Kliniği'ne idrar yapma düzensizlikleri ile getirilen 6'sı kedi, 8'i köpek toplam 14 hayvan araştırmanın materyalini oluşturdu. Anamnez bilgileri, klinik ve bazı laboratuvar bulguları sonucu sistitis tanısı konulan olguların çift kontrast sistografi tekniği ile radyogramları alındı. Bu teknik ile idrar kesesindeki lokal veya yaygın duvar kalınlaşmalan ve dolma defektleri belirlendi. Sistosentez ile alınan idrar örneklerinin uygun besi yerlerinde kültürleri yapıldı. Sekiz köpeğin 5 'inde (\%62) E.coli, 2'sinde (\%25) Proteus spp ve 1'inde (\%12) Klebsiella spp. üredi. Alt1 kediden 4'ünde (\%66), E.coli ürerken 2'sinde üreme olmadı. Antibiyogram sonuçları doğrultusunda tüm hayvanlar enrofloksasin ile antibiyotik tedavisine alındı. Ayrıca tedavi C vitamini ile desteklendi. Yapılan tedavi sonucu 6 kedinin tümü (\%100) ve 8 köpekten 5 'i, 7 gün, 1 'i, 11 gün ve 2 'si 14 gün süren tedavi sonucu tamamen iyileşti. Tedavinin bitirilmesinden iki hafta sonra tekrarlanan kültür sonuçlarında herhangi bir bakteri üremesinin olmaması tedavinin etkinliği ortaya koydu. Sonuç olarak, kedi ve köpeklerde çift kontrast sistografi tekniği ile sistitislerin tanılarının kolaylıkla yapılabileceği belirlendi. Ayrıca sistitis olaylarında en fazla E.coli'nin üremesi, bu ve diğer etkenlerin enrofloksasine duyarlılık göstermeleri nedeniyle kültür ve antibiyogram yapılma olanağı bulunmayan sistitis olgularında antibiyotik olarak enrofloksasinin öncelikle tercih edilmesinin yararłı olacağı kanısına varıldı.

Anahtar kelimeler: Çift kontrast sistografi, enrofloksasin, kedi, köpek, sistitis,

\section{The use of the double contrast cystography technique in the diagnosis of cystitis in cats and dogs and the efficacy of treatment with enrofloxacin}

Summary: The aim of this study was to assess the usefulness of the double contrast cystography technique in the diagnosis of cystitis and the efficacy of enrofloxacin in treatment. A total of 14 animals, namely 6 cats and 8 dogs, brought to the clinic of The Department of Internal Medicine, Faculty of Veterinary Medicine, Ankara University, constituted the material of this research. Radiograms taken by the double contrast cystography technique were examined in cases in which cystitis was diagnosed according to anamnesis together with clinical and laboratory signs. By means of this technique, local and diffused thickening of the wall of the urinary bladder and defects related to filling of the urinary bladder were able to be determined. Urine samples collected by cystosynthesis were cultured in appropriate mediums. Culture results revealed the proliferation of E. coli in $5(62 \%)$, Proteus spp. in 2 (25\%) and Klebsiella spp. in I (12\%) of $8 \mathrm{dogs}$. On the other hand, among the samples collected from 6 cats, 4 (66\%) displayed proliferation of $E$. coli whereas no proliferation was observed in 2 . All animals were administered antibiotic therapy with enrofloxacin according to antibiogram results. Therapy was enhanced by means of Vitamin $\mathrm{C}$ administration. Following treatment, al! 6 cats ( $100 \%$ ) and 5 of the $8 \mathrm{dogs}$ recovered on the fifth day whereas $1 \mathrm{dog}$ and 2 other dogs recovered on the eleventh and fourteenth days, respectively. The observation of no bacterial proliferation in cultures prepared from urine samples collected two weeks after the treatment programme was accomplished, provided evidence for the efficacy of the treatment method. In conclusion, it has been assessed that cystitis could be easily diagnosed in cats and dogs by use of the double contrast cystography technique. Due to the proliferation of mainly E.coli in cystitis cases and the sensitjvity of other causative agents to enrofloxacin, under circumstances in which culture and antibiogram consultation is not possible, it has been concluded that the preference of enrofloxacin for antibiotic therapy would be beneficial.

Key words: Cat, cystitis, dog, double contrast cystography, enrofloxacin

\section{Giriş}

İdrar kesesinin yangısı olarak tanımlanan sistitis kedi ve köpeklerde sık karşılaşılan önemli bir alt üriner sistem bozukluğudur. Köpeklerde kedilere oranla daha yaygın olduğu bildirilmektedir $(2,3,18,19)$. Sistitis'in şekillenmesinde bakteriler önemli rol oynamaktadır. Alt üriner sistemden izole edilen bakteriler genellikle sindirim, deri ve genital sistem orijinli olmakta ve assendan (yukarı çıkan) enfeksiyon şeklinde oluşmaktadır. Nadiren hematojen veya lenfojen yolla da hastalık oluşabilmektedir (3). En fazla rastlanan bakteriler başta E.coli olmak ïzere stafilokoklar, streptokoklar, proteus 
türleri, klebsiella, psödomonas ve enterobakterlerdir (1, $9,15,16,21)$. Ayrıca pastörella, korinebakteri ve mikoplazma türleri ile Bordetella bronchiseptica'nın da enfeksiyonlara neden olabileceği bildirilmiştir $(11,14$, 19). Alt üriner sistemde ve idrarda çok sayıda bakteri bulunmasına rağmen üriner sistemin sahip olduğu savunma sistemleri sayesinde her zaman üreme olanağ bulamazlar $(3,15,19)$. Bu savunma sistemlerinden en önemlileri anatomik olarak bulunan sfinkterler, idrar akışı ve idrar pH'sıdır. Savunma sistemlerinde meydana gelebilecek bozukluklar kısa sürede bakteri üremesi için uygun bir durum yaratmaktadır $(3,10,15)$.

Sistitiste oluşan klinik tablo olayın derecesine bağlı olarak değişiklik göstermektedir. En yaygın karşılaşılan klinik bulgular pollaküri, strongüri, disüri, hematüri ve uzun süre idrar yapma pozisyonunda kalma şeklinde siralanabilir $(4,19)$. Ancak bunlar ürolitiazis, neoplazi, prostatitis vb diğer alt üriner sistem enfeksiyonlarından ayırt edilmesinde yeterli olmamaktadır $(3,15)$.

Alt üriner sistem enfeksiyonlarında tam kan sayımı sonuçları genellikle normaldir. Şiddetli olaylarda ve uterus, prostat ve böbreğin etkilendiği olaylarda lökositoz, nötrofili ve sola kayma saptanabilir. Serum biyokimyasal parametreleri de genellikle normaldir. Tam idrar analizi ve idrar kültürleri tanı için en yararlı tahlillerdir (19).

Ultrasonografi, direkt ve kontrast radyografi tanı için başvurulan görüntüleme metotlarıdır $(5,19,20)$. Ultrasonografi kese duvarının kalınlaştığı durumlarda, ürolitiaziste ve anfizemik yangıların belirlenmesinde yararlı olmaktadır $(7,17)$. Direkt radyografi şiddetli olaylarda yararlı olurken genellikle istenilen düzeyde bilgi verememekte ve kesenin bütünlüğünün ve pozisyonunun net olarak izlenemediği durumlarda kontrast radyografiye gerek duyulmaktadır. Bu teknik ile kese duvan kalınlığı, mukozal düzeydeki değişimler, kese duvarı içindeki kitlelerin varlığı kolaylıkla gösterilebilmektedir $(5,7,26)$.

Enrofloksasin, kinolon grubu bakterisit etkili bir antibakteriyel ajandır. Başlıca böbrekler ve karaciğer yolu ile atılmakta primer eliminasyon tubuler sekresyon ile olmaktadır. İlaç gram pozitif ve gram negatif aerob bakterilerin bir çoğuna ve mikoplazmalara etkilidir (22, 23). Üriner sistem enfeksiyonlarında $5 \mathrm{mg} / \mathrm{kg} / \mathrm{gün}$ dozunda kullanılması önerilmektedir (25).

Bu çalışmada anamnez, klinik, laboratuvar bulguları ve ultrasonografi ile sistitis belirlenen kedi ve köpeklerde idrar kesesinin görüntülenmesinde çift kontrast sistografi tekniğinin yararlığının saptanması ve tedavide enrofloksasinin etkinliğinin araştırılması amaçlanmıştır.

\section{Materyal ve Metot}

Çalışmanın materyalinin Ankara Üniversitesi Veteriner Fakültesi İç Hastalıklar Anabilim Dalı Kliniği'ne idrar yapma duizensizlikleri şikayeti ile getirilen 8'i köpek, 6'sı kedi toplam 14 erkek hayvan oluşturdu. Anamnez bilgilerinden başlayarak hayvan- larm sistematik fiziksel muayeneleri (beden ısısı, inabız, solunum sayıları, mukoza kontrolü vb.) yapıldı. Biyokimyasal ve bakteriyolojik incelemeler içiri idrar örnekleri sistosentez ile alındı. Tam kan sayımlarn için EDTA' $l$, serum çıkarmak için katkısız kan örnekleri vena cephalica accessorius'tan kullanılıp atılan vakumlu tüplere alındı. Elde edilen serumlarda kan üre nitrojeni (BUN) ve kreatinin değerleri Ankara Üniversitesi Veteriner Fakültesi İç Hastalıklar Anabiling Dalı Laboratuvar'ında ölçüldü. Kan üre nitrojeni ö̈lçümlerinde üre Merckotest kiti (Cat No:114315) ve kreatinin ölçümlerinde Jaffe metodu (27) kullanılarak spektrofotometre (Shimadzu) değerleri saptand1.

Böbreklerin ve idrar kesesinin ultrasonografileri 3.5 ve $5 \mathrm{MHz}$ lik konveks proplarla Shimadzu-SSD-450 cihazı kullanılarak yapıldı.

İdrar kesesinin radyografisi çift kontrast sistografi tekniği Radyoloji Bilim Dalı'nda gerçekleştirildi. Kedi ve köpekler ksilazin+ketamin ile uygun dozlarda anesteziye alındıktan sonra idrar kesesine katater yerleştirildi ve idrarın tamamı boşaltıldu. Suda çözünebilen iyotlu kontrast madde (Urografin) (50-200 $\mathrm{mgI} / \mathrm{ml}$ ) kese içine uygun dozlarda (kedilere 20-30 $\mathrm{ml}$, köpeklere büyüiklüklerine göre $100-250 \mathrm{ml}$ ) verildi (7). Daha sonra kedi ve köpeklerin büyüklügüüe göre 4-10 $\mathrm{ml} / \mathrm{kg}$ dozunda hava verilerek (24) radyogramları alındı.

Klinik, laboratuvar ve görüntüleme yöntemleriyle aşağı üriner sistem enfeksiyonu tanısı konan hayvanlardan sistosentez ile alınan idrar örneklerinin jültür ve antibiyogramları Etlik Merkez Veteriner Kontrol Araştırma Enstitüsü'nde yaptırıldı. Antỉbiyogram sonuçları doğrultusunda antibakteriyel olaraki etkenlere duyarlı olduğu saptanan enrofloksasin, ve of vitamini (askorbik asit) ile tedaviye alındı. Enrofloksasin (Baytril-K \% 5 , Bayer) $5 \mathrm{mg} / \mathrm{kg} /$ gün dozunda i.m, klinik semptomlar kaybolana kadar|(7-14 güní) yapıldı. Askorbik asit (Redoxon amp. Roche) $25 \mathrm{mg} / \mathrm{kg} /$ gün i.m. idranı asitleştirmek amacıyla kullanıldı. Idrar kesesinde ürolit tesbit edilen bir kediye bu tedaviye ek olarak Hill's s/d diyeti önerildi. Tedavi bitiminden 2 haftal sonra hayvanlardan tekrar sistosentez ile idrar alınarak kültürler tekrarland1.

\section{Bulgular}

Alınan amamnezde hayvanların idra yapmakta güçlük çektikleri, sık sık idrar yapma istekleri olduğu ve damla damla idrar yaptıkları öğtenildi.

Abdominal palpasyonda 6 kediden 4 'ünde (\%66) idrar kesesinin boş, diğer 2'sinde (\%33) ise kesenin aşırı dolgun olduğu saptand. Idrar kesesi dolu olan 2 kediden birinde orificium urethra eksterna'nın iretral plak diğerinin ise pisi pisi otu ile tıkanmış olduğu saptandı. Dört kedide disüri, strangüri ve hematüri saptandı. Bunlarm 1'inde pyüri (\%25), ,'inde ( $\% 25$ ), ürolitiazis belirlendi. 2 kedide ise üretral tıkanıklığa bağlı anüri saptandı. Köpeklerde idrar kesesinin palpasyonları abdominal defanstan dolayı yapılamadı. Çalışmaya dahil 
edilen 8 köpekten 6'sında pollaküri ve strangüri saptanırken 2'sinde ilave olarak hematüri belirlendi. Tüm hayvanlarda vücut ısısı, nabız ve solunum frekansı değerlerinin normal sınırlar içinde olduğu saptandı. Pyüri saptanan bir kedide belirlenen lökositoz dişında tüm hayvanlarda tam kam sayımı sonuçları normal sınırlar içiñde idi.

Çalışmaya alınan kedi ve köpeklerden elde edilen bazı laboratuvar parametrelerine ait değerler Tablo 1 ve 2' de gösterilmiştir.

Tablo 1: Çalışmaya alınan köpeklere ait laboratuvar bulgulanı Table 1: Laboratory findings of the dogs in the study

\begin{tabular}{|c|c|c|c|c|c|c|c|c|}
\hline$n=8$ & 1 & 2 & 3 & 4 & 5 & 6 & 7 & 8 \\
\hline $\begin{array}{l}\text { Üre } \\
(\mathrm{mg} / \mathrm{d} \mathrm{l})\end{array}$ & 40,6 & 37,56 & 39 & 42,1 & 43 & 38,4 & 36,8 & 38,7 \\
\hline $\begin{array}{l}\text { Kreatinin } \\
(\mathrm{mg} / \mathrm{dl})\end{array}$ & 1,5 & 1,7 & 0,96 & 0,8 & 1,1 & 0,85 & 0,9 & 1,0 \\
\hline WBC $\left(10^{3} / \mu 1\right)$ & 9,89 & 7,66 & 10,08 & 9,47 & 10,1 & 19,65 & 10,03 & 9,6 \\
\hline $\mathrm{RBC}\left(10^{6} / \mu 1\right)$ & 6,31 & 6,44 & 5,62 & 6,33 & 6,42 & 5,74 & 5,57 & 4,67 \\
\hline $\mathrm{Hb}(\mathrm{g} / \mathrm{dl})$ & 14,4 & 14,3 & 12,9 & 13,2 & 14,1 & 12,9 & 12,4 & 10,3 \\
\hline Het $(\%)$ & 41,9 & 43,2 & 38,7 & 41,0 & 36,9 & 39,3 & 37 & 32,2 \\
\hline $\mathrm{PH}$ & 6 & 6 & 6 & 5,5 & 6 & 6,5 & 6,5 & 6,5 \\
\hline Dansite & 1010 & 1020 & 1018 & 1018 & 1009 & 1028 & 1018 & 1044 \\
\hline Lökosit & - & +++ & ++ & ++ & +++ & ++ & +++ & +++ \\
\hline Hematüri & ++ & +++ & + & ++ & + & - & +++ & + \\
\hline Triple Fosfat & - & - & - & - & - & + & - & - \\
\hline Glukoz & - & - & - & - & - & - & - & - \\
\hline Protein & - & + & + & + & + & + & ++ & +++ \\
\hline Kültür & E. coli & E. coli & E. coli & E. coli & E. coli & Proteus spp & Proteus spp & Klebsiella spp \\
\hline
\end{tabular}

Tablo 2: Çalışmaya alınan kedilere ait laboratuvar bulguları

Table 2: Laboratory findings of the cats in the study

\begin{tabular}{|c|c|c|c|c|c|c|}
\hline$n=6$ & 1 & 2 & 3 & 4 & 5 & 6 \\
\hline $\begin{array}{l}\text { Üre } \\
(\mathrm{mg} / \mathrm{dl})\end{array}$ & 53 & 48,3 & 82 & 200 & 315 & 165,85 \\
\hline $\begin{array}{l}\text { Kreatinin } \\
(\mathrm{mg} / \mathrm{dl})\end{array}$ & 1,3 & 1,1 & 1,8 & 5,4 & 10.2 & 8,5 \\
\hline WBC $\left(10^{3} / \mu \mathrm{I}\right)$ & 9 & 19 & 7,7 & 5,8 & 10,1 & 9,82 \\
\hline $\operatorname{RBC}\left(10^{6} / \mu 1\right)$ & 6,5 & 8,4 & 6,4 & 8,46 & 7,3 & 6,1 \\
\hline $\mathrm{Hb}(\mathrm{g} / \mathrm{dl})$ & 12 & 13,2 & 13 & 14,3 & 13,7 & 14 \\
\hline Hct $(\%)$ & 42 & 45 & 39,5 & 43,6 & 41,2 & 40,0 \\
\hline PH & Hafif alkali & Alkali & Alkali & Hafif alkali & Alkali & Hafif alkali \\
\hline Dansite & 1050 & & 1065 & 1037 & 1027 & 1024 \\
\hline Lökosit & ++ & +++ & + & + & + & + \\
\hline Hematüri & +++ & +++ & + & +++ & +++ & +++ \\
\hline Triple fosfat & - & - & - & - & - & - \\
\hline Glukoz & - & - & - & - & - & - \\
\hline Protein & - & ++ & + & +++ & +++ & +++ \\
\hline Kültür & E.coli & E.coli & E.coli & - & - & E.coli \\
\hline
\end{tabular}


Tüm olgularda idrarın biyokimyasal incelenmesinde; idrarların alkali karakterde olduğu, değişik oranlarda kan ve protein içerdiği belirlendi. Idrar dansitesi kedilerde 1015-1065, köpeklerde 1009-1047 olarak belirlendi. İdrar sedimentinin incelenmesinde 3 10 adet lökosit, pyürili kedide çok sayıda lökosit ve eritrosit, bir kedide ise triple fosfat kristalleri belirlendi.

İdrarın bakteriyolojik incelenmesinde, 6 kediden 4 'ünde (\%66) E.coli ürerken, 2'sinde (\%33) herhangi bir üreme olmadi. Sekiz köpekten 5'inde (\%62) E.coli, 2 'sinde (\%25) Proteus spp ve l'inde (\%12) Klebsiella spp. üredi.

Serum üre ve kreatinin değerleri; obstrüksiyon bulunan 2 kedide sirasiyla $315,10.2 \mathrm{mg} / \mathrm{dl}$ ve $200,5.4$ $\mathrm{mg} / \mathrm{dl}$, kronik renal yetmezlik durumu da belirlenen bir kedide sirasiyla 165, 8.5 olarak belirlendi. Diğer hayvanlarda değerler normal sınırlar içinde idi.

İdrar kesesinin ultrasonografik muayenesinde, değişik oranlarda kese duvarı kalınlaşmaları, ekojenite artışları ve bir kedide kese içinde $11.9 \mathrm{~mm}$ çapında idrar taşı belirlendi.

İdrar kesesinin çift kontrast sistografi tekniği ile çekilen radyografik görüntülerinden bir örnek Şekil-1' de gösterilmiştir. Bu teknik ile alınan filmlerde kesedeki yaygın veya lokal duvar kalınlaşmaları ve dolma defektleri kolaylıkla belirlenmiştir.

Yapilan tedavi sonucu 6 kedinin tümui (\%100) ve 8 köpekten 5'i (\%62.5), 7 gün, 1'i (\%12.5), 11 gün ve 2'si (\%25) 14 gün süren tedavi sonucu klinik olarak tamamen iyileşti. Tedavinin bitirilmesinden iki hafta sonra tekrarlanan kültür sonuçlarında herhangi bir bakteri üremesi olmadı.

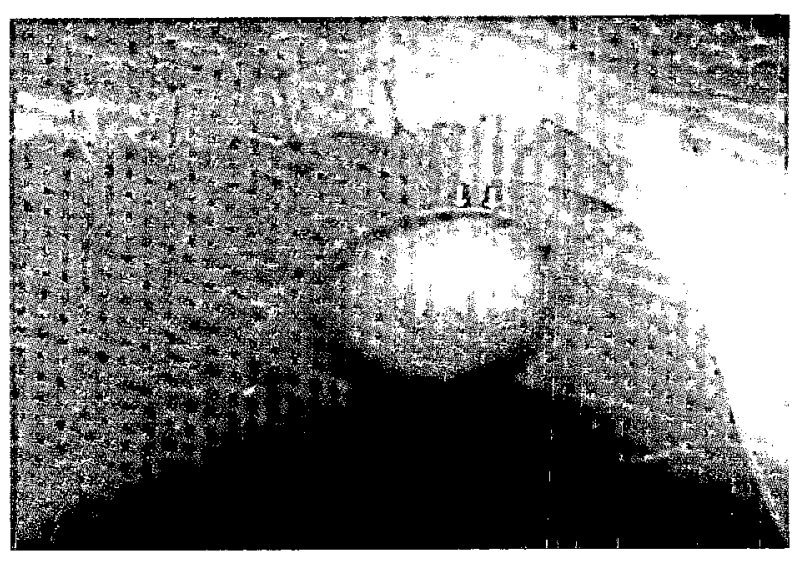

Şekil 1: İdrar kesesinde çift kontrast sistografi ile dolma defektinin tespiti

Figure 1: Detection of filling detect in the urinary bladder by double contrast cystography.

\section{Tartışma ve Sonuç}

Kedi ve köpeklerde aşağ disüri, pollaküri, hematüri, strangüri, kristalüri ve üretral obstrüksiyon gibi semptomların biri veya birkaçının birlikte görüldüğü yaygın problemlerdir $(12,13,14)$.
Nitekim bu çalışmanın gerçekleştirildiği Ankara Üniversitesi Veteriner Fakültesi İç Hastalıklar Anabilim Dalı Kliniği'ne hastalıklar nedeniyle getirilen kedi ve köpeklerde aşağı üriner sistem enfeksiyonları önemli bir yer tutmaktadir.

Alt üriner sistem enfeksiyonuna E.coli, stafílokok, streptokok, proteus, klebsiella, psödomonas ve enterobakterlerin neden olabileceği bildirimlerine (16) benzer olarak bu çalışmada idrar kültürlerinde kedilerde \%66.6, köpeklerde \% 62.5 oranında E.coli, köpeklerde $\% 25$ oranında Proteus spp. ve \%12.5 oranında Klebsiella spp. üremiştir. Enfeksiyon bir bakteri türünden ya da birkaç bakteri türünün işe kanşmasıyla oluşabilmektedir $(18,25)$. Lees ve Rogers (15) çalışmasında inceledikleri köpeklerin \% 16 sinda 2 veya daha fazla etken izole ettiklerini bildirmişlerdir. Bu çalışmada her olguda tek bir bakteri izole edilmiştir.

Kedilerde aşağı üriner sistem hastalıklarınnda herhangi bir bakteri üretilememesi durumu ile sıklıkla karşılaşılmaktadır (12). Bu çalışmada da 2 kedide herhangi bir bakteri üremesi ile karşılaşılmamış ólması bu bildirime uygun olmuştur.

Çift kontrast radyografi idrar kesesi intraluminal dolma defektleri ve mukozal yüzeydeki lezyonların değerlendirilmesi ve uretral divertiküllerin saptanması gibi bir çok idrar kesesi bozukluğundal kullanılması önerilmektedir $(5,6,7)$. Bu çalışmaya alınan kedi ve köpeklerde çift kontrast sistografi sonucunda idrar kesesinde yaygin ve lokal duvar kalınlaşmaları ve dolma defektleri kolaylukla belirlenmiştir. Yöntemin direkt grafi ve pozitif kontrast üretrosistografiye göre daha faydalı olduğu kanısındayız.

Antibiyotik seçiminde ideal yol etken izolasyonu ve antibiyogram yapılmasıdır. Ancak gerekli laboratuvar olanaklarına ulaşılamadığı durumlarda ve zaman kaybetmemek için etkili olabileceği düşünülen bir antibiyotik ile tedaviye başlanması pratik bir uygulamadır. Dowling (8), benzer olarak enrofloksasinin stafilokok, bazı streptokok ve enterokoklar, E.coli, proteus, klebsiella ve psödomonas gibi bakteriler üzerinde bakterisidal etkisi ve yüksek derecede suda çözünébilme özelliklerinden dolayı tercih edilebileceğini bildirmektedir. Bu çalışmada antibiyogram sọnuçları doğrultusunda antibakteriyel ilaç olarak Enrofloksasin 7 14 gün süreyle kullanılmış ve hayvanların klinik ollarak iyileştiği saptanmıştır. Tedavi bitiminden 2 hafta sonra yapılan kontrollerde idrar kültürlerinin normal olması kullanılan ilaçların etkili olduğunu göstermektedir.

Sonuç olarak, kedi ve köpeklerde çift lkontrast sistografi tekniği ile sistitis tanısının kolaylıkla yapılabileceği belirlendi. Ayrıca sistitis olaylarında en fazla E.coli'nin üremesi, bu ve diğer etkenlerin enrofloksasine duyarlılık göstermeleri nedeniyle kültür ve antibiyogram yapılma imkanı bulunmayan sistitis olgularinda antibiyotik olarak enroflokşasinin öncelikle tercih edilmesinin yararlı olacağı kanısına varıldi 


\section{Kaynaklar}

1. Allen T, Jones R, Purvance J (1987): Microbiologic evaluation of canine urine: Direct microscopic examination and preservation of specimen quality for culture. JAVMA, 190, 1289-1291.

2. Bartges JW, Barsanti JA (2000): Bacterial Urinary Tract Infection In Cats. 880-882. In: JD Bonagura (Ed), Kirk's Current Veterinary Theraphy XIII Small Animal W.B. Saunders, Philadelphia.

3. Blanco LJ, Bartges JW (2001): Understanding and eradicating bacterial urinary tract infections. Vet Med, 96, 776-790.

4. Buffington CAT, Chew DJ, Kendall MS, Scrivani PT, Thompson S, Blaisdell JL, Woodsworth BE (1997): Clinical evaluation of cats with nonobstructive urinary tract diseases. JAVMA, 210, 46-50.

5. Burk RL, Ackermen N (1996): Small Animal Radiology and Ultrasonography a Diagnostic Atlas and Text. W.B. Saunders, Philadelphia.

6. Chew DJ, Buffington T, Barthez P (1999): Diagnosis of nonobstructive lower urinary tract diseases in cats. Waltham Focus, 9, 2-7.

7. Dennis R (1996): Diagnostic lmaging of the Urinary Tract. 124-147. In: J Bainbridge (Ed), BSAVA Manuel of Canine and Feline Nephrology and Urology. Fusion Design, Fordingbridge.

8. Dowling PM (1996): Antimicrobial therapy of urinary tract infections. Can Vet $\mathrm{J}, \mathbf{3 7}, 438-41$.

9. Féria C, Machado J, Correia DJ, Gonçalves J, Gaastra W (2001): Distribution of papG alleles among uropathogenic Escherichia coli isolated from different species. FEMS Microbiol Letters, 202, 205-208.

10. Holt PE (1999): Diagnosis and management of canine urethral sphincter mechanism incompetence. Waltham Focus, 9, 19-23.

11. Ihrke PJ, Norton AL, Long GV, Standart AA (1985): Urinary tract infection assosiated with long-term corticosteroid administration dogs with chornic skin diseases. JAVMA, 186, 43-46.

12. Kruger JM (1991): Clinical evaluation of cats with lower urinary tract disease. JAVMA, 199, 211-216.

13. Kruger JM, Osborne CA (1993): The role of uropathogens in feline lower urinary tract disease. Vet Clin North Am (Small Anim Pract), 23, 101-123.

14. Lees GE (1996): Bacterial urinary tract infections. Vet Clin North Am (Small Anim Pract), 26, 297-305.

15. Lees GE, Rogers KS (1986): Diagnosis and Localization of Urinary Tract Infection. 1118-1123. In: RW Kırk (Ed),
Current Veterinary Teraphy IX. Small Animal Practice. W.B. Saunders, Philadelphia.

16. Lees GE, Rogers KS (1986): Treatment of urinary tract infections in dogs and cats. JAVMA, 189, 648-652.

17. Léveillé R (1998): Ultrasonography of urinary bladder disorders. Vet Clin North Am (Small Anim Pract), 28 799-821.

18. Ling GV (1984): Therapeutic strategies involving antimikrobial treatment of the canine urinary tract. JAVMA, 185, 1162-1164.

19. Lulich JP, Osborne CA, Bartges JW, Polzin DZ (1995): Canine Lower Urinary Tract Disorders. 1833. 1861. In: SJ Ettinger (Ed), Textbook of Veterinary Internal Medicine, W.B. Saunders, Philadelphia.

20. Nyland TG, Natton JS (1995): Veterinary Diagnostic Ultrasound. W.B. Saunders, Philadelphia.

21. Oxenford CJ, Lomas GR, Love DN (1984): Bacteriuria in the dog. J Small Anim Pract, 25, 83-91.

22. Papich MG (1995): Antimicrobial Drugs. 272-283. In: SJ Ettinger (Ed), Textbook of Veterinary Internal Medicine, W.B. Saunders, Philadelphia.

23. Polzin DJ (1997): Management of recurrent bacterial urinary tract infections. Comp Contin Educ, 19, 47-52.

24. Pugh CR, Rhodes WH, Biery DN (1993): Contrast studies of the urogenital system. Vet Clin North Am (Small Anim Pract), 23, 281-306.

25. Rogers K, Lees G (1989): Management of Urinary Tract Infections. 1204-1208 In: RW Kirk (Ed), Current Veterinary Teraphy IX. Small Animal Practice. W.B Saunders, Philadelphia.

26. Scrivani PV, Chew DJ, Buffington CAT, Léveillé R, Kendall MS (1997): Result of retrograde uretrography in cats with idiopathic, nonobstructive lower urinary tract disease and their assocations with pathogenesis; 53 cases (1993-1995) JAVMA, 211, 741-748.

27. White WL, Erikson MM, Steven SC (1976): Chemistry for the Clinical Laboratory. $4^{\text {th }}$ edition. The C.V. Mosby Co., St. Louis.

Geliș Tarihi 21.04.2003 Kabul Tarihi 25.06.2003

\section{Yazışma Adresi:}

Doç. Dr. Aslan KALINBACAK

Ankara Üniversitesi Veteriner Fakültesi

$I_{C}$ Hastallklar ABD.

06110 Dişkapı/ANKARA 